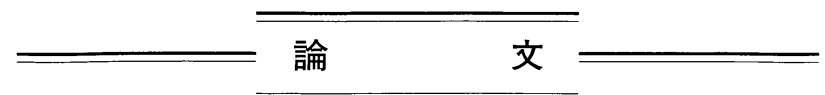

農業気象(J.Agric. Meteorol.) 54 (1): 1-11, 1998

\title{
Spatial Variability of Urban Surface Heat Fluxes Estimated from Landsat TM Data under Summer and Winter Conditions
}

\author{
Xiaochuan Zhang, Yasuyuki Aono and Nobutaka Monsi \\ Lab. of Atmospheric Environment, College of Agriculture, \\ Osaka Prefecture University, Gakuen-cho 1-1, Sakai, 599-8531 Japan
}

\begin{abstract}
This paper proposes a method to estimate the urban surface heat fluxes using Landsat TM data in conjunction with routine data from meteorological observatory and direct field measurement data. The sensible and latent heat fluxes are evaluated independently using bulk transfer formulae. The ground cover classification, surface albedo, surface temperature and the normalized difference vegetation index (NDVI) are deduced from two Landsat TM images on Aug. 6, 1990 and Dec. 6, 1988. A field measurement is carried out to obtain the relationship between the moisture availability and relative humidity for no-vegetation ground using band-pass covariance technique to measure the turbulent sensible and latent heat fluxes over concrete surface.

The distribution of each pixel and mean value for each kind of ground cover show that the net radiation in urban area has a relatively conservative behavior with little spatial variability. Conversely, the sensible and latent heat fluxes have clear spatial variability. The high sensible heat flux corresponds to high building (urban center) and residential area, while the relatively low sensible heat flux corresponds to forest area in parks and open water. The latent heat flux is very low in high building and wooden residential area (mean values less than $37 \mathrm{Wm}^{-2}$ in summer and $1 \mathrm{Wm}^{-2}$ in winter). But in residential area with some vegetation and forest area, latent heat flux increases to 77 and $194 \mathrm{Wm}^{-2}$, and the mean Bowen ratio decreases to 4.6 and 1.6 in summer, respectively. Since the amount and activity of vegetation is higher in summer, there is a greater spatial variability of heat fluxes in summer than in winter.
\end{abstract}

Key words: Bulk transfer method, Landsat TM data, Surface heat flux, Urban area.

\section{Introduction}

It is difficult to estimate the heat fluxes over an urban surface since urban area represents the complex combination of different land uses. There were many studies which dealt with the energetic behaviors of the urban system (Oke, 1988). However, most of the studies were to use the single point to represent the areal average of spatial complex region. This may result in errors on the surface energy balance due to spatial misrepresentation. As mentioned by Schmid et al. (1991), the positioning of instruments can significantly affect the validity of flux measurement; in

Presented at the Annual General Meeting on June 7, 1997. Received on June 25, 1997.

Accepted on October 17, 1997. order to evaluate spatial variations of the energy balance, a detailed study of small scale (10-1000 $\mathrm{m}$ ) is needed. But such work is very difficult to be completed over a whole urban area since the density of measurement sites can not be high enough to satisfy the requirement.

With the development of high-space-resolution satellites, some key surface parameters used for calculating the surface heat flux can be remotely monitored (Sellers et al., 1990). The independent, consistent and economically feasible remote sensed data can be provided over the whole city. There were some studies (Brutsaert et al., 1993; Kaneko and Hino, 1994; Aono et al., 1996) estimating regional surface heat fluxes using satellite data for forest area. But such studies are found scarcely for urban area. 
The objective of present study is to develop the method of using satellite data in conjunction with routine meteorological and direct field measurement data to calculate the surface heat fluxes for urban area in the case of Osaka city. The Landsat TM data will be used to obtain the surface ground cover classification, surface albedo, surface temperature and NDVI. In order to investigate the characteristics of moisture availability for no-vegetation ground, the direct field measurement of sensible and latent heat fluxes using eddy correlation approach with band-pass covariance technique is carried out over concrete ground, and the relationship between relative humidity and moisture availability will be obtained. The sensible and latent heat fluxes will be calculated independently using bulk transfer equations. We will show the spatial variability of urban surface heat fluxes under summer and winter conditions.

\section{Data and Preliminary Analysis}

\subsection{Study area and ground cover classification}

In order to analyze the seasonal change of heat fluxes, we used two Landsat-5 TM images sensed over Osaka city at 0940 JST on Aug. 6, 1990 and Dec. 6, 1988 as the representative conditions in summer and winter. The geometric correction was firstly carried out through the affine transformation which is based on 7 ground control points to determine the coefficients for two coordinate transformation equations. Then the orientation of pixel array on the distorted image can be altered to be parallel with the Universal Transverse Mercator Coordinate. The study area (Fig. 1) was about 120 $\mathrm{km}^{2}$ in rectangular. Each scene includes $349 \times 355$ pixels, and each pixel has the size of $31.8 \mathrm{~m} \times 30.8 \mathrm{~m}$ in latitudinal and longitudinal direction. Six kinds of ground covers were introduced as the categories of ground cover and classified using the Gaussian maximum likelihood classifier (Fig. 2). The mean accuracy for the training data of the first classification into open water, urban area, forest area, and bare land using the combination of band 1, 2, 3 and 4 is $92 \%$. And then we used the combination of band 1, 3, 4 and 5 to classify the urban area into high building area, wooden residential area and residential area with some vegetation.

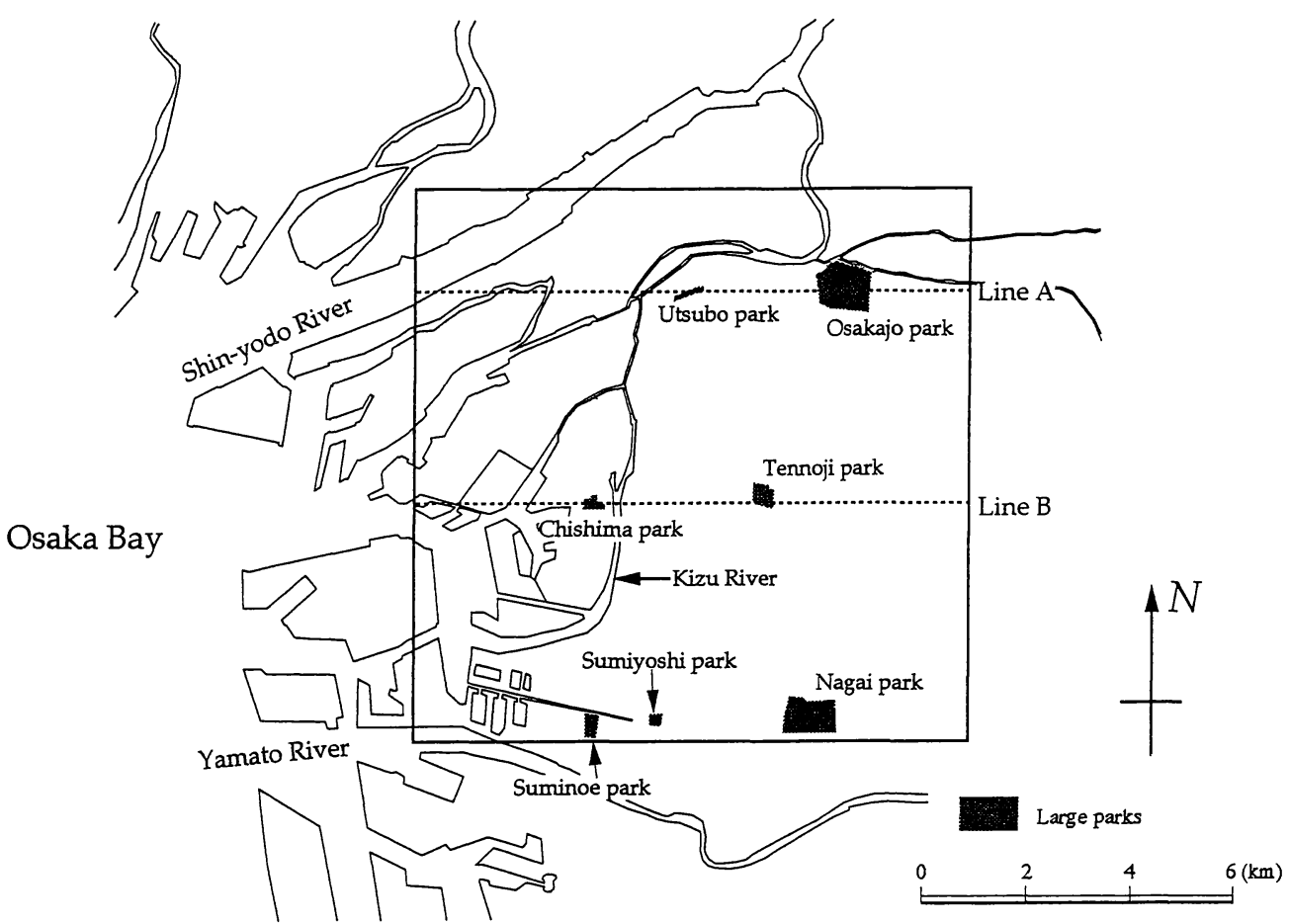

Fig. 1. Location of study area. Dashed lines A and B are used to examine net radiation, sensible and latent heat fluxes in cross section. 


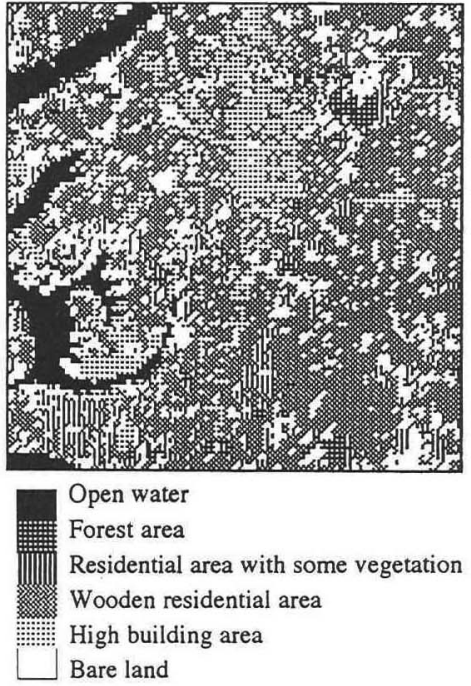

Fig. 2. Ground cover classification obtained from TM data on Aug. 6, 1990.

\subsection{The routine meteorological data and surface parameters}

The routine meteorological data for the estimation of heat budget terms were shown in Table 1. The values of $R_{\mathrm{s}}, P, T_{\mathrm{a}}, e, q_{\mathrm{a}}$ and $U$ at 0940 JST were interpolated from the measurements by the Osaka District Meteorological Observatory at 0900 and 1000 JST on the same day of Landsat passing over Osaka. The solar elevation, and the ozone amounts calculated from monthly mean value at Tateno and Kagoshima, were necessary to estimate the distribution of surface albedo.

Some surface parameters such as the average height $h$, the zero-plane displacement $d_{0}$, and the roughness length for momentum $z_{\mathrm{m}}$ and heat $z_{\mathrm{h}}$ for each pixel, were show in Table 2. $24 \times 26$ mesh data of story $(500 \mathrm{~m} \times 500 \mathrm{~m}$ per mesh, Planning Bureau of Osaka City, 1995) were interpolated and overlaid to TM image to determine $h$ for building area. $h$ for forest area was set at $10 \mathrm{~m}$, as a typical value of height of trees in parks of Osaka city area. As mentioned by Arya (1988), $d_{0}$ in an urban boundary layer can be expected to be a large fraction of the average building height. So $d_{0}$ was arbitrarily set to be equal to two thirds of $h . z_{\mathrm{m}}$ for building area was assumed according to the results of previous studies (Kono et al., 1988; Kondo and Yamazawa, 1983; Kimura and Takahashi, 1991; Hiyama et al., 1996). For open water, forest area and bare land, the value of $z_{\mathrm{m}}$ proposed by Kondo (1994), Aono et al. (1996) and Arya (1988) was used, respectively. The value of $z_{\mathrm{h}}$ was given to be a constant according to Kimura and Takahashi (1991) for building area, Garratt (1978) for forest area $\left(z_{\mathrm{m}} / z_{\mathrm{h}}=12\right)$, and Kondo (1994) for open water and bare land.

The height $z$ for heat flux estimation was set to be at $10 \mathrm{~m}$ above $h$ for each pixel. $U, P, T_{\mathrm{a}}$ and $q_{\mathrm{a}}$ were corrected to that height for each pixel. $U$ was corrected by power-law profile with an exponent of one third. $T_{\mathrm{a}}$ at $z$ was extrapolated by using the measurement values from observatory data at

Table 1 Variables used in estimation of net radiation, sensible and latent heat fluxes. All values are at $1.5 \mathrm{~m}$ height, except for $U$.

\begin{tabular}{lcc}
\hline \multicolumn{1}{c}{ Variable } & Aug. 6, 1990 & Dec. 6, 1988 \\
\hline Downward short wave radiation; $R_{\mathrm{S}}\left(\mathrm{Wm}^{-2}\right)$ & 680.6 & 323.6 \\
Air pressure; $P(\mathrm{hPa})$ & 994.8 & 1016.9 \\
Air temperature; $T_{\mathrm{a}}(\mathrm{K})$ & 303.8 & 280.3 \\
Water vapor pressure; $e(\mathrm{hPa})$ & 22.1 & 5.6 \\
Specific humidity; $q_{\mathrm{a}}\left(\mathrm{gkg}^{-1}\right)$ & 14.0 & 3.4 \\
Wind speed; $U\left(\mathrm{~ms}^{-1}\right.$, at $\left.53 \mathrm{~m}\right)$ & 2.3 & 2.0 \\
Solar elevation $\left({ }^{\circ}\right)$ & 55 & 27 \\
Ozone amount $(\mathrm{atm}-\mathrm{cm})$ & 0.290 & 0.288 \\
\hline
\end{tabular}

Table 2 Surface parameters of Osaka city for each type of ground cover.

\begin{tabular}{|c|c|c|c|c|}
\hline Type of ground cover & $h(\mathrm{~m})$ & $z_{\mathrm{m}}(\mathrm{m})$ & $z_{\mathrm{h}}(\mathrm{m})$ & $\varepsilon$ \\
\hline Open water & 0 & $0.27 \times 10^{-4}$ & $0.79 \times 10^{-4}$ & 0.993 \\
\hline High building area & stories $\times 3.5$ & \multirow{3}{*}{$\begin{array}{l}d_{0} \geqq 6, z_{\mathrm{m}}=1.5 \\
d_{0}<6, z_{\mathrm{m}}=1.0\end{array}$} & \multirow{3}{*}{$10^{-3}$} & \multirow{3}{*}{0.966} \\
\hline Wooden residential area & stories $\times 2.5$ & & & \\
\hline Residential area with vegetation & stories $\times 2.5$ & & & \\
\hline Forest area & 10 & 0.45 & 0.0375 & 0.986 \\
\hline Bare land & 0 & $10^{-3}$ & $10^{-4}$ & 0.980 \\
\hline
\end{tabular}


$1.5 \mathrm{~m}$ height and satellite-derived mean surface temperature around the observatory assumed as the air temperature at $z_{\mathrm{h}}(0.001 \mathrm{~m})$.

\subsection{Surface albedo}

Surface albedo $A$ was estimated using the method proposed by Nakagawa and Ooi (1992) for Landsat MSS data, after modified by Aono et al. (1996) for TM data. The planetary albedo $A_{\mathrm{p}}$ which includes effects of absorption and scattering in atmosphere can be directly derived from reflectance measured by sensors of TM, considering the irradiation from the space on each day. In this method, Rayleigh scattering and absorptions by ozone and water vapor were considered in the calculation using the parameters described by Lacis and Hansen (1974) and Liou and Sasamori (1975), then the relationships

$$
\begin{aligned}
& A=1.136 A_{\mathrm{p}}-0.02431 \text { (on Aug. 6, 1990) } \\
& A=1.135 A_{\mathrm{p}}-0.04278 \text { (on Dec. 6, 1988) }
\end{aligned}
$$

were derived to calculate $A$ for each pixel.

Although this $A$ is for the wave band of TM coverage which is $45 \%$ of the whole solar energy, it was assumed that this $A$ was used to represent the albedo for whole wavelength of solar energy in this study.

The mean surface albedo for each kind of ground cover was shown in Table 3. The lowest albedo was observed from open water, the highest one was the bare land. In the building area, especially in urban center, high building area has low mean value of $A$, compared with surrounding residential areas in both seasons. The albedo on Aug. 6 was obviously higher than that on Dec. 6 ,

Table 3 Mean values of albedo $A$, surface temperature $T_{\mathrm{s}}$, and NDVI for each type of ground cover derived from TM data on Aug. 6, 1990

\begin{tabular}{|c|c|c|c|c|}
\hline & Type of ground cover & $A$ & $T_{\mathrm{s}}\left({ }^{\circ} \mathrm{C}\right)$ & NDVI \\
\hline \multirow{6}{*}{ 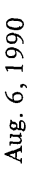 } & Open water & 0.03 & 32.6 & -0.34 \\
\hline & High building area & 0.09 & 47.2 & -0.14 \\
\hline & Wooden residential area & 0.10 & 48.5 & -0.10 \\
\hline & Residential area with vegetation & 0.11 & 47.4 & -0.02 \\
\hline & Forest area & 0.12 & 43.1 & 0.25 \\
\hline & Bare land & 0.14 & 46.2 & -0.07 \\
\hline \multirow{6}{*}{$\begin{array}{l}\infty \\
\infty \\
0 \\
\\
\hat{0} \\
\dot{0} \\
\dot{0} \\
0\end{array}$} & Open water & 0.03 & 11.5 & -0.34 \\
\hline & High building area & 0.06 & 12.8 & -0.17 \\
\hline & Wooden residential area & 0.07 & 12.5 & -0.13 \\
\hline & Residential area with vegetation & 0.08 & 12.7 & -0.10 \\
\hline & Forest area & 0.08 & 10.9 & -0.01 \\
\hline & Bare land & 0.08 & 11.6 & -0.12 \\
\hline
\end{tabular}
and Dec. 6, 1988. except for open water. This may be due to the effect of number of days after raining. There was a rain one day before Dec. 6 , but it rained 8 days before Aug. 6. So the surface was wetter on Dec. 6 than that on Aug. 6 .

\subsection{Surface temperature}

The thermal infrared band 6 of TM was used to calculate the surface temperature. In this study, the Osaka bay sea-surface temperature measured by the Osaka Prefecture Fisheries Experimental Station on the same day of Landsat passing was used to calibrate the radiometric brightness of band 6 . Within a narrow range of surface temperature for analysis in this study, the linear relationship between the sea-surface blackbody temperature and the digital number of band 6 can be obtained for each date, and then the surface temperature for each kind of ground cover was obtained by the Stefan-Boltzmann law including the emissivity $\varepsilon$ (Table 2) for each ground cover.

The distributions of surface temperature on Aug. 6 and Dec. 6 were shown in Fig. 3. The mean value of surface temperature for each kind of ground cover was shown in Table 3. On Aug. 6, surface temperatures of building areas and bare land (more than $45^{\circ} \mathrm{C}$ ) were higher than those of forest area (less than $45^{\circ} \mathrm{C}$ ) and open water (less than $35^{\circ} \mathrm{C}$ ) where much heat may be lost through evapotranspiration. On Dec. 6, surface temperature pattern had less contrast among ground covers than that on Aug. 6, but still there were little higher surface temperatures in building areas and bare land $\left(11-13^{\circ} \mathrm{C}\right)$ than those in forest area and open water $\left(10-12^{\circ} \mathrm{C}\right)$.

\subsection{Vegetation index}

The latent heat flux for each pixel would be influenced by the amount of vegetation. Satellitederived vegetation indices were proposed by many workers (Baret and Guyot, 1991; Baret, 1995; Rondeaux et al., 1996). These indices are closely related to vegetation amount or leaf area index. In this study, NDVI was used to indicate the vegetation amount in each pixel and to relate with the moisture availability for surfaces with vegetation. NDVI is computed from the difference between digital number of visible red band 3 and that of near infrared band 4 divided by the sum of the two.

The mean value of NDVI (Table 3) changed with 

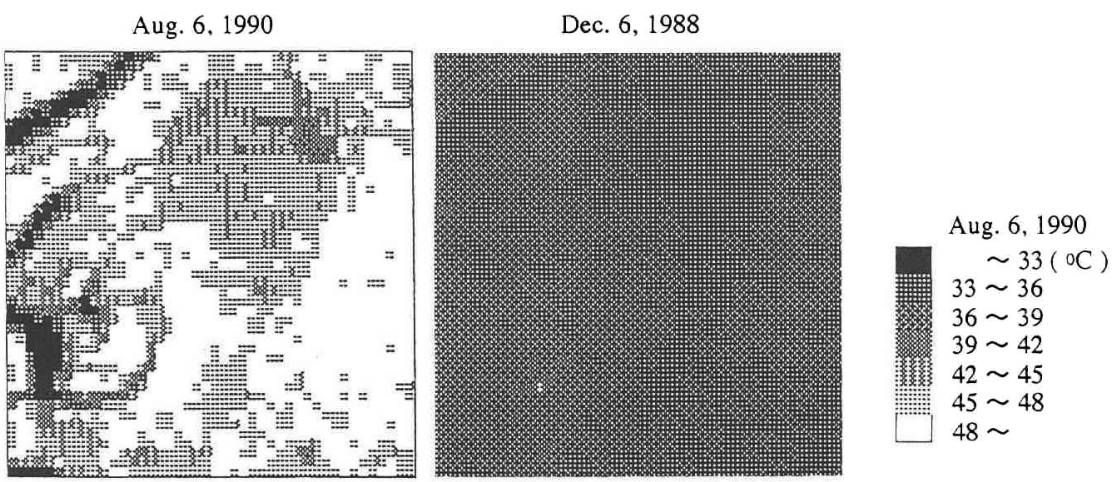
Dec. 6, 1988
$\sim 9(\mathrm{oC})$
$9 \sim 12$
$12 \sim 15$
$15 \sim 18$
$18 \sim 21$
$21 \sim 24$
$24 \sim$

Fig. 3. Distribution of surface temperature on Aug. 6, 1990 and Dec. 6, 1988 at 0940 JST.

vegetation amount (from -0.14 in high building area to 0.25 in forest area on Aug. 6). All values, especially that value for forest area, decreased on Dec. 6 due to the smaller amount and inactivity of vegetation in winter, except for open water (for further describe see Zhang et al., 1996).

\section{Method}

Interpolated meteorological variables and given surface parameters were applied to estimate heat budget terms for each pixel. The surface energy balance can be expressed as

$$
R_{\mathrm{n}}=H+\lambda E+G
$$

where $R_{\mathrm{n}}$ is the net radiation, $H$ the sensible heat flux, $\lambda E$ the latent heat flux, and $G$ the ground heat flux. All terms are in the units of $\mathrm{Wm}^{-2} \cdot R_{\mathrm{n}}$ is given from a radiation balance at the surface

$$
R_{\mathrm{n}}=R_{\mathrm{s}}(1-A)+\varepsilon R_{\mathrm{L}}-\varepsilon \sigma T_{\mathrm{s}}^{4}
$$

where $\sigma$ is the Stephan-Boltzmann constant (5.67 $\left.\times 10^{-8} \mathrm{Wm}^{-2} \mathrm{~K}^{-4}\right) . \quad T_{\mathrm{s}}$ is surface temperature $(\mathrm{K})$. $R_{\mathrm{L}}$ is the downward longwave radiation $\left(\mathrm{Wm}^{-2}\right)$ estimated using a method proposed by Swinbank (1963)

$$
R_{\mathrm{L}}=1.2 \sigma T_{\mathrm{a}}^{4}-171
$$

$H$ and $\lambda E$ are determined using bulk transfer equations expressed as

$$
\begin{aligned}
& H=\rho C_{\mathrm{p}} C_{\mathrm{h}} U\left(T_{\mathrm{s}}-T_{\mathrm{a}}-\Gamma z\right) \\
& \lambda E=\rho \lambda C_{\mathrm{e}} U \beta\left(q_{\mathrm{sat}}-q_{\mathrm{a}}\right)
\end{aligned}
$$

where $\rho$ is the density of air $\left(\mathrm{kgm}^{-3}\right), C_{\mathrm{p}}$ the specific heat at constant pressure $\left(\mathrm{J} \mathrm{kg}^{-1} \mathrm{~K}^{-1}\right), \lambda$ the latent heat of vaporization $\left(\mathrm{Jg}^{-1}\right)$, and $\Gamma$ the temperature adiabatic lapse rate $\left(0.0098 \mathrm{~K} \mathrm{~m}^{-1}\right)$; $q_{\text {sat }}$ is the surface saturation specific humidity of $T_{\mathrm{s}}\left(\mathrm{g} \mathrm{kg}^{-1}\right) ; C_{\mathrm{h}}$ and $C_{\mathrm{e}}$ are the bulk transfer coefficients for heat and moisture (here we assumed
$C_{\mathrm{h}}=C_{\mathrm{e}}$ ), respectively; $\beta$ is the moisture availability.

Based on the Monin-Obukhov similarity theory, $C_{\mathrm{h}}$ can be formulated as

$$
C_{\mathrm{h}}=\frac{k^{2}}{\left[\ln \left(\frac{z-d_{0}}{z_{\mathrm{m}}}\right)-\Psi_{\mathrm{m}}\right]\left[\ln \left(\frac{z-d_{0}}{z_{\mathrm{h}}}\right)-\Psi_{\mathrm{h}}\right]}
$$

where $k$ is the von Karman constant $(0.41), \Psi_{\mathrm{m}}$ and $\Psi_{\mathrm{h}}$ are functions of stability parameter $\zeta$ which can be related to the bulk Richardson number $R_{\mathrm{B}}$

$$
R_{\mathrm{B}}=\frac{g}{T_{\mathrm{s}}} \frac{T_{\mathrm{a}}-T_{\mathrm{s}}+\Gamma z}{U^{2}}\left(z-d_{0}\right)
$$

where $g$ is acceleration of gravity $\left(9.8 \mathrm{~m} \mathrm{~s}^{-2}\right)$. According to Aono et al. (1996), the relationship between $R_{\mathrm{B}}$ and $\zeta$ was assumed as $\zeta=c R_{\mathrm{B}}$ using mean value of $d_{0}, z_{\mathrm{m}}$ and $z_{\mathrm{h}}$ for each ground cover, and this result was applied to estimate $\zeta$ for each pixel. Coefficient $c$ was evaluated as 15.7 for open water, 0.9 for high building area, 1.2 for wooden residential area and residential area with some vegetation, 2.8 for forest area and 8.8 for bare land. $H$ can be calculated for each pixel using the relation between $R_{\mathrm{B}}$ and $\zeta$, variables and parameters in equation (6).

For calculation of $\lambda E$ using equation (7), the moisture availability $\beta$ should be determined for each pixel. In this study, we assumed that there was a transition of moisture transfer from evapotranspiration to only evaporation according to the decline of vegetation amount. We used NDVI as the indicator of representative vegetation amount. We set -0.15 of NDVI, derived from mean value of high building area, as the threshold of evapotranspiration in moisture transfer.

When NDVI $<-0.15$, the surface was almost no vegetation coverage, the evaporation process 
was mainly influenced by the evaporation from impervious surface. The study of Kondo et al. (1990) for bare soil surface showed that $\beta$ depended on the volumetric soil moisture $\theta$ and $U$. But $\theta$ is difficult to be obtained from the surfaces of forest or buildings. Okuda (1996) investigated the relationship of $\beta$ with relative humidity $R H, U$ and $R_{\mathrm{s}}$ from direct measurement for a forest. The result showed that $\beta$ has a strong relation with $R H$ and weak relations with $U$ and $R_{\mathrm{s}}$. In this study, we try to establish the relationship between $\beta$ and $R H$ from direct measurement over concrete ground.

The observation program was conducted on Aug. 20 and 21, 1996 at the courtyard of Agriculture College building, Osaka Prefecture University. The ground is covered by concrete. The surrounding buildings have four floors height and are paved by ceramic tile. The effect of humidity on $\beta$ was surveyed by measurements under various humidity conditions made by sprinkling on the second observation day.

If the $C_{\mathrm{h}}$ is assumed to be equal to $C_{\mathrm{e}}, \beta$ can be calculated from Eqs. (6) and (7) by

$$
\beta=\frac{\overline{w^{\prime} q^{\prime}}\left(T_{\mathrm{s}}-T_{\mathrm{a}}\right)}{\overline{w^{\prime} T^{\prime}}\left(q_{\mathrm{sat}}-q_{\mathrm{a}}\right)}
$$

where $w^{\prime}, T^{\prime}$, and $q^{\prime}$, are the fluctuations of vertical velocity, temperature as well as humidity, which were measured through the sonic anemometer and the fine thermocouple for dry and wet bulb temperatures, respectively. $T_{\mathrm{s}}$ was measured with a radiation thermometer. The other thermocouple was used to observe $T_{\mathrm{a}}$ and $q_{\mathrm{a}} \cdot \overline{w^{\prime} q^{\prime}}$ was corrected by the calculation of $\overline{w^{\prime} T^{\prime}}$ with band-pass covariance technique (Hicks and McMillen, 1988), using the pass range $0.001-0.04 \mathrm{~Hz}$. Because the observation height was only $1.2 \mathrm{~m}$ above ground, we omitted $\Gamma z$ in Eq. (10).

The relationship of $\beta$ and $R H$ was regressed as $\beta=2 \times 10^{-5} \cdot \exp (0.094 \cdot R H) \quad(r=0.38)$

The correlation of this relation was low in this observation due to the very small value of $\beta$ which is difficult to be observed, the problems of instrument and sampling, and so on. The more investigation should be done in the future. But as a way to get $\beta$ from $R H$, we still use this relation in present study. The application of $R H$ values on Aug. 6 and Dec. 6 showed $\beta$ of $2.25 \times 10^{-3}$ and $2.93 \times 10^{-3}$, respectively.
When NDVI $\geqq-0.15$, it means there were some vegetative coverage in one pixel, and $\beta$ dominated by evapotranspiration was defined as (Kaneko and Hino, 1994)

$$
\beta=\beta_{\mathrm{s}} \cdot a_{\mathrm{NDVI}}
$$

where $\beta_{\mathrm{s}}$ is the stomatal aperture. The value of $\beta_{\mathrm{s}}$ was set as 0.19 for Aug. 6, determined in a study (Aono et al., 1997) for Ikoma Mountain. $\beta_{\mathrm{s}}$ is usually influenced by wind speed and humidity. Because the wind speed on Dec. 6 was almost the same as that on Aug. $6, \beta_{\text {s }}$ was assumed only affected by humidity and determined as 0.25 on Dec. 6.

$a_{\mathrm{NDVI}}$ is evapotranspiration area index defined as

$$
a_{\mathrm{NDVI}}=\frac{\mathrm{NDVI}-\mathrm{NDVI}_{0}}{\mathrm{NDVI}_{100}-\mathrm{NDVI}_{0}}
$$

where $\mathrm{NDVI}_{0}$ is the minimum value of NDVI when the ground is no-vegetation coverage, leading $a_{\mathrm{NDVI}}$ to zero. $\mathrm{NDVI}_{100}$ is the maximum value of NDVI when there are very dense forest, leading $a_{\text {NDVI }}$ to 1 . In this study, the highest NDVI (0.75) observed from Ikoma Mountain was selected to be the NDVI ${ }_{100}$. When the surface was covered with sufficiently vigorous vegetation $(\mathrm{NDVI}=0.75$, $\left.a_{\mathrm{NDVI}}=1\right), \beta$ is equal to the value of $\beta_{\mathrm{s}}$. Then maximum of $\lambda E$ would be evaluated. $\mathrm{NDVI}_{0}$ was deduced as -0.1608 on Aug. 6 and -0.1607 on Dec. 6 from Eq. (12) and (13) using the critical value of NDVI $(-0.15), \beta$ of $2.25 \times 10^{-3}$ and 2.93 $\times 10^{-3}$, and $\beta_{\mathrm{s}}$ of 0.19 and 0.25 , respectively.

\section{Results and Discussion}

A summary of the mean values of $R_{\mathrm{n}}, H, \lambda E$ and Bowen ratio $B(H / \lambda E)$ for each ground cover on Aug. 6, 1990 and Dec. 6, 1988 is shown in Table 4. The distribution of $H$ and $\lambda E$ is shown in Fig. 4. Two cross sections along line $\mathrm{A}$ and $\mathrm{B}$ in Fig. 1 were selected to represent the variation of $R_{\mathrm{n}}, H$ and $\lambda E$ (Fig. 5, Fig. 6). The cross section of line A passes two large parks, some rivers and urban center area between the two parks. That for line B passes port, residential area from Kizu river to the east end of the map, two large parks, and some canals and rivers. The cross section for each heat budget term was depicted using the moving average over five pixels.

\subsection{Net radiation}

The spatial variability of $R_{\mathrm{n}}$ was relatively small in urban area. Mean values for different ground 
Table 4 Mean values of $R_{\mathrm{n}}, H, \lambda E$ and $B$ for each type of ground cover on Aug. 6, 1990 and Dec. 6, 1988.

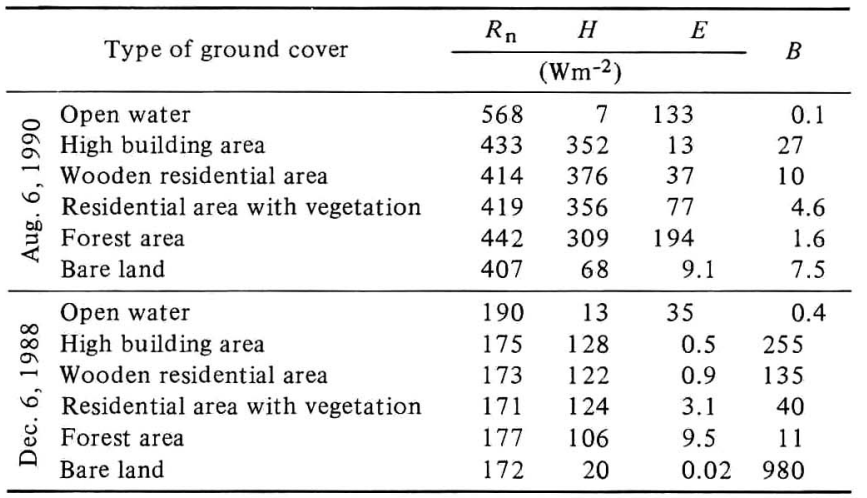
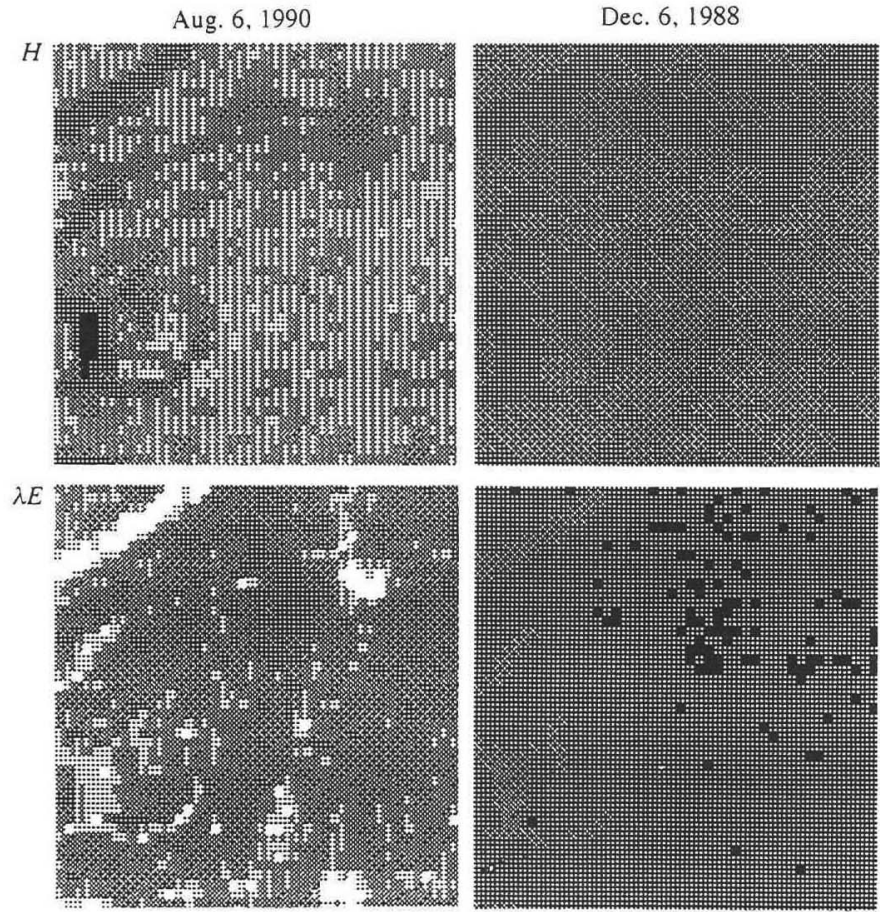

Fig. 4. Distribution of $H$ and $\lambda E$ on Aug. 6, 1990 and Dec. 6, 1988 at 0940 JST.

covers (Table 4) fell into $407-442 \mathrm{Wm}^{-2}$ on Aug. 6, and $172-177 \mathrm{Wm}^{-2}$ on Dec. 6, except for open water. Although there was a wide range of surface materials in the city, the net short- and long-wave radiation differences may be limited due to the albedo-surface temperature feedback process explained by Schmid et al. (1991). This result can be well depicted using cross sections (Fig. 5, Fig. 6). The highest peak (near $580 \mathrm{Wm}^{-2}$ ) and several small peaks of $R_{\mathrm{n}}$ appear at the locations corre- sponding to Shin-yodo, Dojima and Tosabori rivers in cross line A, and Osaka port, Tempozan canal, Shirinashi and Kizu river in cross line B. Values of $R_{\mathrm{n}}$ for other ground covers fluctuate with small changes. The fluctuation of $R_{\mathrm{n}}$ cross line becomes much weaker in winter than that in summer.

\subsection{Sensible and latent heat fluxes}

Comparing with net radiation, the sensible and latent heat fluxes showed clear spatial variability. It is easily found from $H$ and $\lambda E$ in Table 4 and 


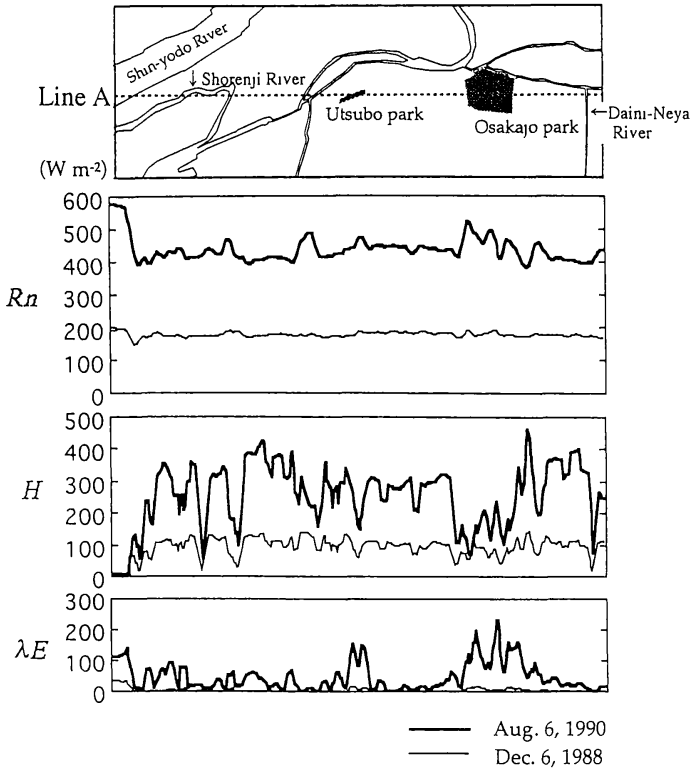

Fig. 5. Cross section of $R_{\mathrm{n}}, H$ and $\lambda E$ along image line A observed on Aug. 6, 1990 (thick line) and Dec. 6, 1988 (thin line) at 0940 JST.

Fig. 4 that the high sensible heat flux corresponds to high building (urban center) and residential areas, while the relatively low sensible heat flux corresponds to forest area in parks and open water. The latent heat flux is very low in high building and wooden residential area (mean values less than $37 \mathrm{Wm}^{-2}$ in summer and $1 \mathrm{Wm}^{-2}$ in winter). But in residential area with some vegetation and forest area, latent heat flux increases to 77 and 194 $\mathrm{Wm}^{-2}$, and the mean Bowen ratio decreases to 4.6 and 1.6 in summer, respectively. $\lambda E$ becomes very low in winter, even for forest area where $B$ is about 11. On Aug. 6, $\lambda E$ in forest area was larger than that in open water because of higher $T_{\mathrm{s}}$ in forest than that in open water. On Dec. 6 , higher $\lambda E$ was estimated for open water than that for forest, since low activity and little vegetation amount of the forest in this season was capable of less transpiration than that in summer. The contrast of $H$ or $\lambda E$ changed small in winter. The estimation of $H$ tended to change mainly according to surface temperature. On the other hand, the increase of $\lambda E$ was attributed to the change of $a_{\mathrm{NDVI}}$, representing the succession of vegetation amount from urban with impervious surface to forest.

$H$ for bare land and open water may be underestimated due to the effect of incorrect assumption

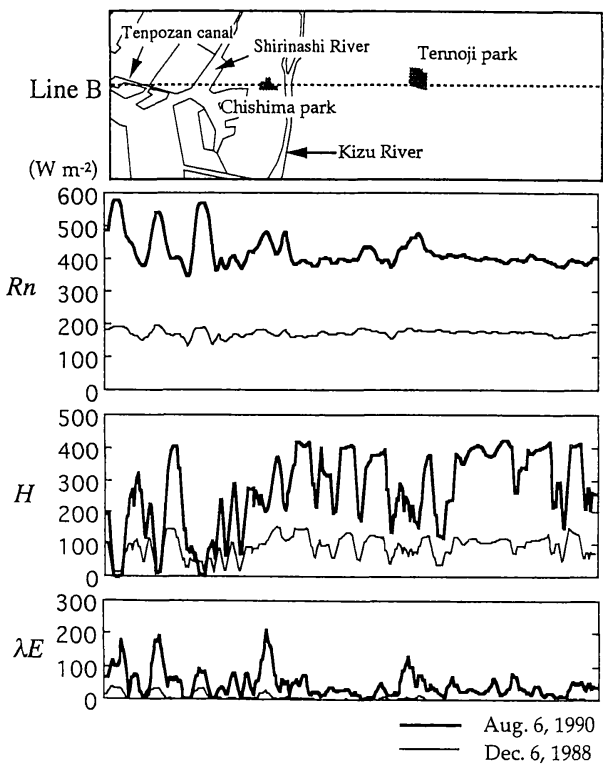

Fig. 6. Cross section of $R_{\mathrm{n}}, H$ and $\lambda E$ along image

line B observed on Aug. 6, 1990 (thick line) and Dec. 6, 1988 (thin line) at 0940 JST.

for surface parameters of $z_{\mathrm{m}}$ and $z_{\mathrm{h}}$. We set these parameters to be the values used for homogeneous surfaces of bare land and open water. However, non-building open ground classified into bare land and the river or water body classified into open water in this study area are usually surrounded by buildings, then $z_{\mathrm{m}}$ and $z_{\mathrm{h}}$ should not be as small as those for homogeneous surfaces leading to a relatively large value of $\ln \left(\left(z-d_{0}\right) / z_{\mathrm{m}}\right)$ in equation (11) and a relatively small $C_{\mathrm{h}}$, and resulting in the low $H$. Conversely, $H$ for other types of ground cover may be estimated larger than real one. These may also be effected by the unsuitable surface parameters. For example, if $z_{\mathrm{h}}$ is set to be not as small as the suitable value, then $C_{\mathrm{h}}$ may be estimated relatively large leading to $H$ overestimated. Sun and Marht (1995) showed that $z_{\mathrm{h}}$ depended on the flow and was poorly related to $z_{\mathrm{m}}$. In this sense, it was a poorly defined parameter. So further studies are needed since it is important to set reasonable surface parameters to predict the correct heat fluxes when using bulk transfer equations. Besides the effect of unsuitable surface parameters, other factor such as the difference of resolution of band 6 from other bands may also affect the accuracy of estimation.

The surface heterogeneity of Osaka city is well 
defined by the large fluctuation of $H$ and $\lambda E$ in Fig. 5 and Fig. 6. Most of the peaks of $H$ coincide with the dips of $\lambda E$ in the residential area and urban center, while most of the peaks of $\lambda E$ coincide with the dips of $H$ in rivers and parks. Along with the cross section of line A from west to east for $H$ (Fig. 5), the deepest dip (near $5 \mathrm{Wm}^{-2}$ ) is firstly observed in Shin-yodo river. The section where cross line passes across some rivers and parks shows corresponding dips of about $200 \mathrm{Wm}^{-2}$. Much of the rest of residential area and urban center appear like a plateau near $320 \mathrm{Wm}^{-2}$ for Aug. and 100 $\mathrm{Wm}^{-2}$ for Dec. with interrupted by the dips mentioned above. The highest peak with value about $465 \mathrm{Wm}^{-2}$ may be corresponding to the tall building of apartment house near the railway yards of JR and Osaka municipal subway where the surface temperature was very high (more than $55^{\circ} \mathrm{C}$ ). The difference of $H$ in urban center and wooden residential area can also be found easily in Fig. 5. $H$ for urban center fluctuates below $320 \mathrm{Wm}^{-2}$, while that for residential area may fluctuate over 320 $\mathrm{Wm}^{-2}$. $\lambda E$ along cross section of line A shows that the peaks are corresponding to rivers, Utsubo and Osaka-jo parks. The peaks occurred in parks are higher than that in rivers. The urban center has very low $\lambda E$ as a basin. The rest of fields with hillock of $\lambda E$ may be corresponding to the residential area with some vegetation. There are several pixels where low $H$ are not corresponding to high $\lambda E$ (e.g., cross points at Shorenji river and Daini-Neya river). These are the results of error classification of ground cover. If the ground cover of open water is mistakenly classified into other types of ground cover, although the sensor of band 6 can detect a low $T_{\mathrm{s}}$, then the moisture availability will be set much smaller leading to a low $\lambda E$ in this pixel.

The similar results for $H$ and $\lambda E$ can also be obtained along with the cross section of line B (Fig. 6). Three deepest dips of $H$ and peaks of $\grave{\lambda} E$ are observed in Osaka port, Tempozan canal and Shirinashi river. The same results are also correspondingly found in Chishima park, Kizu River, and Tennoji park. The plateau of $H$ (about $400 \mathrm{Wm}^{-2}$ ) corresponding to the residential area is more frequently interrupted by valleys. The reason is that more pixels belonged to residential area with some vegetation were passed through this cross section. The highest of $\lambda E\left(220 \mathrm{Wm}^{-2}\right)$ is represented in Chishima park.

The magnitude and the fluctuation of cross lines for $H$ and $\lambda E$ become small in winter.

\section{Conclusions}

A method of using Landsat TM data in conjunction with the routine data from meteorological observatory and direct field measurement data to estimate the urban surface heat fluxes is proposed and applied to Osaka city. The ground cover classification, surface albedo, surface temperature and NDVI were determined from two TM images on Aug. 6, 1990 and on Dec. 6, 1988 to represent the situations in summer and winter. In order to obtain the moisture availability for no-vegetation covered building area, a field measurement was carried out using eddy correlation approach and band-pass covariance technique to measure the turbulent heat fluxes over concrete surface under different conditions of relative humidity.

The spatial variability of net radiation was small with a relatively conservative behavior in spite of the surface heterogeneity in Osaka city. On the other hand, sensible and latent heat fluxes showed clear spatial variability. The high sensible heat flux corresponded to high building (urban center) and residential area, while the relatively low sensible heat flux corresponded to forest area in parks and open water. The latent heat flux is very low in high building and wooden residential area (mean values less than $37 \mathrm{Wm}^{-2}$ in summer and $1 \mathrm{Wm}^{-2}$ in winter). But in residential area with some vegetation and forest area, latent heat flux increases to 77 and $194 \mathrm{Wm}^{-2}$, and the mean Bowen ratio decreases to 4.6 and 1.6 in summer, respectively. $\lambda E$ became very low in winter, even for forest area where $B$ was about 11 . Because the activity and amount of vegetation is higher in summer leading to a larger differences of surface properties, the spatial variability both for net radiation and turbulent heat fluxes was larger on Aug. 6, 1990 than that on Dec. 6, 1988.

In order to obtain more accurate estimation of heat fluxes, further studies are needed to get more reasonable surface parameters and effective value of $\beta_{\mathrm{s}}$ since little is known about these behaviors in urban areas now. 


\section{Acknowledgments}

The authors would like to thank Dr. H. Kono (Environment and Public Health Bureau of Osaka City) and Dr. T. Hosino (College of Engineering, Osaka Prefecture University) for providing useful supplemental data and helpful comments.

\section{References}

Aono, Y., Koda, H., Zhang, X. and Monji, N., 1996: Hest budget estimation of a forest area using LANDSAT TM data. J. Agric. Meteorol., 52, 221-231. (in Japanese)

Aono, Y., Kudo, T. and Monji, N., 1997: An evaluation of heat budget in forest area using LANDSAT/TM data. - Change in heat budget according to weather condition -. Proc. Meet. Soc. Agric. Meteorol. Jpn., 98-99. (in Japanese)

Arya, S. P., 1988: Introduction to Micrometeorology. Academic Press, INC., San Diego, 307pp.

Baret, F., 1995: Use of spectral reflectance variation to retrieve canopy biophysical characteristics. In Advances in Environmental Remote Sensing (ed. by Danson, F. M. and Plummer, S. E.). Jone Wiley \& Sons, Chichester, p.33-51.

Baret, F. and Guyot, G., 1991: Potentials and limits of vegetation indices for LAI and APAR assessment. Remote Sens. Environ., 35, 161173.

Brutsaert, W., Hsu, A. Y. and Schmugge, T. J., 1993: Parameterization of surface heat fluxes above forest with satellite thermal sensing and boundary-layer soundings. J. Appl. Meteorol., 32, 909-917.

Garratt, J. R., 1978: Transfer characteristics for a heterogeneous surface of large aerodynamic roughness. Quart. J. Roy. Meteorol. Soc., 104, 491-502.

Hicks, B. B. and McMillen, R. T., 1988: On the measurement of dry deposition using imperfect sensors and in non-ideal terrain. BoundaryLayer Meteorol., 42, 79-94.

Hiyama, T., Sugita, M. and Kotoda, K., 1996: Regional roughness parameters and momentum fluxes over a complex area. J. Appl. Meteorol., $35,2179-2190$.

Kaneko, D. and Hino, M., 1994: A method for evaluation of surface energy balance in regional forests using normalized difference vegetation index derived from LANDSAT TM and routine meteorological data. J. Japan Soc. Hydrol. Water Resour., 7, 10-21. (in Japanese)

Kimura, F. and Takahashi, S., 1991: The effects of land-use and anthropogenic heating on the surface temperature in the Tokyo metropolitan area: A numerical experiment. Atmos. Environ.,
25B, 155-164.

Kondo, J., 1994: Meteorology of the water environment - Water and heat balance of the earth's surface. Asakura Shoten, Tokyo, p. 93-127. (in Japanese)

Kondo, J., Saigusa, N. and Sata, T., 1990: A parameterization of evaporation from bare soil surfaces. J. Appl. Meteorol., 29, 385-389.

Kondo, J. and Yamazawa, H., 1983: Surface wind speed and aerodynamic roughness over complex ground surfaces. Tenki, 30, 553-561. (in Japanese)

Kono, H., Fujimoto, A. and Nakano, H., 1988: A NOx diffusion simulation in an urban area by using the $\sigma_{z}$ including a surface roughness parameter. Tenki, 35, 189-197. (in Japanese)

Lacis, A. A. and Hansen, J. E., 1974: A parameterization for the absorption of solar radiation in the earth's atmosphere. J. Atmos. Sci., 31, $118-133$.

Liou, K. and Sasamori, T., 1975: In the transfer of solar radiation in aerosol atmospheres. $J$. Atmos. Sci., 32, 2166-2177.

Nakagawa, K. and Ooi, Y., 1992: The surface albedo distribution and its seasonal change over the Nagaoka area, Niigata Prefecture, central Japan, estimated from LANDSAT/MSS data. Geograph. Review, 65A, 769-790. (in Japanese)

Oke, T. R., 1988: The urban energy balance. Prog. Phys. Geogr., 12, 471-508.

Okuda, J., 1996: Study on estimation method for regional evapotranspiration of forest. M. Agric. Thesis, $100 \mathrm{pp}$. (in Japanese)

Planning Bureau of Osaka City, 1995: Osaka mesh data. Vol. 18. (in Japanese)

Rondeaux, G., Steven, M. and Baret, F., 1996: Optimization of soil-adjusted vegetation indices. Remote Sens. Environ., 55, 95-107.

Schmid, H. P., Cleugh, H. A., Grimmond, C. S. B. and Oke, T. R., 1991: Spatial variability of energy fluxes in suburban terrain. BoundaryLayer Meteorol., 54, 249-276.

Sellers, P. J., Rasool, S. I. and Bolle, H., 1990: A review of satellite data algorithms for studies of the land surface. Bull. Amer. Meteorol. Soc., 71, 1429-1447.

Sun, J. and Marht, L., 1995: Determination of surface fluxes from the surface radiative temperature. J. Atmos. Sci., 52, 1096-1106.

Swinbank, W. C., 1963: Long-wave radiation from clear skies. Quart. J. Roy. Meteorol. Soc., 89, 339-348.

Zhang, X., Aono, Y. and Monji, N., 1996: Relationship among surface temperature, vegetation index and ground cover in Osaka city area using Landsat TM data. Bull. Univ. Osaka Prefect., Ser. B, 48, 45-54. 


\title{
ランドサットT Mデータによる夏季・冬季 の都市熱収支分布の評価
}

\author{
張 暁川・青野靖之・文字信貴
}

(大阪府立大学農学部大気環境学研究室)

要約

地球観測衛星ランドサットのTMデータを用いて夏季 (1990年8月6日) と冬季(1988年12月6日)の日中にお ける大阪市市街地の地表面熱収支の分布を推定した。顕 熱・潜熱フラックスの推定には各々のバルク輸送式を用 い, 必要なデータを内挿し画素でとに計算した。解析に 要するデータのうち, 土地被覆, 地表面アルベド, 表面 温度, NDVIの分布については, TM データから直接計 算した。その他, 気温などについては, 気象台のデータ を併用して推定した。潜熱フラックスの計算に必要な蒸 発散効率 $\beta$ にいては, 植生のない市街地に見たてた地 点での実地観湘結果によって求めた。
都心及び住宅密集地では, 市内でも顕熱フラックスは 高く，潜熱フラックスはほとんどない結果となった。一 方, 特に夏季, 市内の都市公園では, 平均 $194 \mathrm{Wm}^{-2}$, また, 植生の多い住宅地でも, $77 \mathrm{Wm}^{-2}$ 程度の潜熱フラ ックスが評価された。こうした熱フラックスの土地被覆 による違いは冬季よりあ夏季で顕著だった。これは, 表 面温度の市内に拈ける分布パターン, そして潜熱フラッ クスに限ればNDVI から見た植生量, 活性が評価結果に 影響したことによる。

キーワード : 地表面熱フラックス, 都市域, バルク法, ランドサットTMデータ 